\title{
PARTITIONING COLLAGENOLYTIC ENZYME FROM Cichla Ocellaris USING AQUEOUS TWO-PHASE SYSTEMS (PEG-PHOSPHATE) AND APPLICATIONS OF PEPTIDES FOR PHARMACEUTICAL PURPOSES
}

\author{
V. M. OLIVEIRA ${ }^{1}$, T. P. NASCIMENTO ${ }^{2}$, W. W. C. ALBUQUERQUE ${ }^{1}$, M. N. C. \\ CUNHA ${ }^{1}$, C. A. LIMA $^{3}$, D. A. V. MARQUES ${ }^{4}$, A. L. F. PORTO ${ }^{1,2}$. \\ ${ }^{1}$ Universidade Federal Rural de Pernambuco, Departamento de Morfologia e Fisiologia \\ Animal \\ ${ }^{2}$ Laboratório de Imunopatologia Keizo Asami (LIKA), Universidade Federal de Pernambuco \\ ${ }^{3}$ Universidade de Pernambuco, Faculdade de Ciências, Educação e Tecnologia de Garanhuns \\ ${ }^{4}$ Universidade de Pernambuco, Campus de Serra Talhada
}

E-mail para contato: thiago_pajeu@hotmail.com

ABSTRACT: A collagenolytic protease obtained of Cichla ocellaris was extracted by polyethylene glycol (PEG)/phosphate aqueous two-phase system (ATPS). For this purpose, a $2^{4}$-full factorial design was applied using PEG molar mass, PEG concentration, phosphate salt concentration and $\mathrm{pH}$ as independent variables, and the purification factor (PF), partition coefficient $(K)$ and activity yield $(Y)$ as responses. The ATPS was composed of PEG at concentrations of $12.5,15.0$ and $17.5 \%(w / w)$ and phosphate at concentrations of $10.0,12.5$ and $15.0 \%(w / w)$. The best extraction results (K: 3.57, Y: 119\%, PF: 8.24) were obtained at pH 8.0 using $17.5 \%(w / w)$ PEG 8000 and $15.0 \%(w / w)$ phosphate. The optimum temperature was $55^{\circ} \mathrm{C}$, with optimal activity at $\mathrm{pH}$ 7.5. The enzyme was activated by $\mathrm{Ca}^{2+}$ and inhibited by $\mathrm{Zn}^{2+}$, and had its activity reduced when exposed to PMSF and TLCK, having been able to cleave type I collagen, suggesting potential in the production of peptides.

Keywords: aqueous two-phase system; collagen hydrolysis; digestive protease; collagen peptide; fish waste.

RESUMO: Uma protease colagenolitíca obtida a partir de Cichla ocellaris foi extraida por sistema de duas fases aquosas (SDFA)- polietilenoglicol (PEG)/fosfato. Para este fim, um planejamento fatorial $2^{4}$-completo foi utilizado usando massa molar de PEG, concentração de PEG, concentração de fosfato e pH como variáveis independentes, tendo o fator de purificação (FP), coeficiente de partição $(K)$ e rendimento de atividade $(Y)$ como respostas. O SDFA foi composto de PEG em concentrações de 12,5, 15,0 e 17,5\% (p/p) e fosfato a concentrações de 10,0, 12,5 e 15,0\% (p/p). Os melhores resultados de extração (K: 3,57, Y: 119\%, FP: 8,24) foram obtidos no $\mathrm{pH} 8,0$ usando $17,5 \%(p / p)$ de $P E G 8000$ e $15,0 \%$ ( $p / p)$ de fosfato. A temperatura ótima da enzima foi de $55^{\circ} \mathrm{C}$, com atividade ideal a pH 7,5. A enzima foi ativada por $\mathrm{Ca}^{2+}$ e inibida por $\mathrm{Zn}^{2+}$, e 
teve sua atividade reduzida quando exposta a PMSF e TLCK, tendo conseguido clivar o colágeno do tipo I, sugerindo potencial na produção de peptídeos.

Palavras-chave: sistema de duas fases aquosas; hidrólise de colágeno; protease digestiva; peptídeo de colágeno; resíduo de peixe.

\section{INTRODUCTION}

Partitioning in aqueous two-phase systems (ATPS) is a suitable method for separating and purifying mixtures of biomolecules. ATPS generates two immiscible aqueous phases, which can be applied to the recovery and purification of biological products such as proteins, enzymes, nucleic acids, viruses, antibodies and cell organelles (HATTI-KAUL,2001; RAJA et al., 2011).

PEG/phosphate system has been widely used due to the fact that PEG presents favorable physical properties that provide viscosity and density differences between the phases in addition to its low cost (RAJA et al., 2011). Collagenases represent a group of enzymes that hydrolyze the peptide bonds of various types of collagen. After the collagen hydrolysis by collagenase, the collagen peptides are formed bioactive molecules that act as hypotensive agents (ACE inhibitory), mineral-binding, antimicrobial, immunomodulatory, cytomodulatory, antithrombotic, antioxidant and hypocholesterolemic (HARTMANN and MEISEL, 2007; ERDMANN et al., 2008). Digestive viscera of fish such as intestines and caeca are rich sources of enzymes that have the property of decomposing collagen, particularly enzymes from the group of serinocollagenases (KIM et al., 2002; PARK et al., 2002) becoming a potential source of relevant as source of new products to the industrial enzyme market.

Research efforts have aimed to investigate new peptides that provide health benefits. Under these assumptions, this study aimed to extract/concentrate a protease with collagenolytic properties of the Neotropical fish peacock bass Cichla ocellaris. For this purpose, a $2^{4}$-full factorial design was applied to the process to identify the optimal levels of PEG molar mass, $\mathrm{pH}$, phosphate and PEG concentrations for pre-purification or extraction of the collagenolytic protease. Finally, the main biochemical properties of the extracted collagenolytic protease were determined and the enzyme application in the hydrolysis of collagen was investigated.

\section{MATERIAL AND METHODS}

\subsection{Fish waste and obtaining enzymatic crude extract}

Waste of viscera of peacock bass Cichla ocellaris were obtained from the colony of fishermen colony of Petrolândia, Pernambuco, Brazil. The material was kindly provided after evisceration process. Samples of intestine $(500 \mathrm{~g})$ were collected separately, packaged in plastic containers, kept on ice, where they were stored at $-27^{\circ} \mathrm{C}$ for further processing. The processing of waste was performed in accordance to the methods of Oliveira et al. (2017). The best fraction of the supernatant was subjected to a recovery process in aqueous two-phase system (ATPS).

2.2 Extraction steps of collagenolytic protease

2.2.2 Preparation of the aqueous two-phase systems

Aqueous two phase systems were prepared in $15 \mathrm{~mL}$ graduated tubes with $40 \%(\mathrm{w} / \mathrm{w})$ phosphate salt mixture and 50\% (w/w) PEG solution at different $\mathrm{pH}$ values $(6.0,7.0,8.0)$ at 
$25 \pm 1\left({ }^{\circ} \mathrm{C}\right)$ according to the statistical design described in 2.3.3. Different concentrations of monobasic sodium phosphate and dibasic potassium phosphate were used depending on the $\mathrm{pH}$ required. After vortex shaking for $1.0 \mathrm{~min}$, the two phases were separated by settling for $60 \mathrm{~min}$. Then, the top and bottom phases were measured and analyzed separately. Both phases were assayed for protein concentration and collagenolytic activity in the further steps.

\subsection{Analytical techniques}

2.3.1 Azocoll assay for collagenase activity and Protein determination

The collagenolytic activity was determined according to the protocol of Oliveira et al. (2017), while protein determination followed protocol established by Smith et al. (1985).

2.3.3 Experimental design and determination of partition coefficient, yield and purification factor

A $2^{4}$-full factorial design was utilized to evaluate the influence of the four independent variables, namely PEG molar mass, PEG concentration, phosphate salt concentration and $\mathrm{pH}$ on the selected responses: Partition coefficient $(K)$, purification factor $(P F)$ and Yield of the collagenolytic protease partial purification $(Y)$. The $K$ for collagenolytic protease activity in the aqueous two-phase system was defined as the ratio of enzymatic activity $(\mathrm{U} / \mathrm{mL})$ in the top phase (At) to that in the bottom phase (Ab) (Eq. 1):

$$
K=\frac{A_{t}}{A_{b}}
$$

The PF was calculated as the ratio of the specific activity of collagenolytic protease in the top phase and initial specific activity of crude extract. Specific activity $(\mathrm{U} / \mathrm{mg})$ is given by the ratio between volumetric activity $(\mathrm{U} / \mathrm{mL})$ and protein concentration $(\mathrm{mg} / \mathrm{mL})$ (Eq. 2):

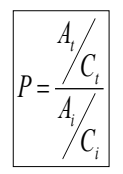

At and $\mathrm{Ai}$ are collagenolytic protease activity in the top phase and in the initial crude extract, respectively; $\mathrm{Ct}$ and $\mathrm{Ci}$ are total protein concentrations, expressed as $\mathrm{mg} / \mathrm{mL}$, in the top phase and crude extract, respectively.

The (Y\%) was determined as the ratio of collagenolytic protease activity (At) $(\mathrm{U} / \mathrm{mL})$ in the top phase and that in the crude extract (Ai) (U/mL) expressed as percentage (eq. 3):

$$
Y=\left(\frac{A_{t}}{A_{i}}\right) \cdot 100
$$

\subsection{Characterization of the extracted PEG-collagenolytic protease}

Optimum temperature and $\mathrm{pH}$ - The effect of the temperature on the enzyme activity and stability was evaluated at temperatures ranging from 25 to $90^{\circ} \mathrm{C}$. To determine the optimum temperature, the collagenolytic assays were carried out at constant temperatures (incubated in water bath). The activity was calculated as percentage activity compared to the one obtained at the optimum temperature (considered as 100\%). To determine the optimum $\mathrm{pH}$, the collagenolytic assays were carried out in different $\mathrm{pH}$ ranges using the buffers: $0.5 \mathrm{M}$ citrate- 
phosphate ( $\mathrm{pH}$ 4.0-7.0), 0.1 M Tris- $\mathrm{HCl}(\mathrm{pH} 7.5-8.5)$ and $0.1 \mathrm{M}$ glycine- $\mathrm{NaOH}$ ( $\mathrm{pH}$ 9.0-12.0) containing $5 \mathrm{mM} \mathrm{CaCl} 2$. The optimum $\mathrm{pH}$ was defined as the $\mathrm{pH}$ in which the maximum activity was detected, compared in terms of percentage (KIM et al., 2002, PARK et al., 2002). Effect of metal ions - The effect of metal ions on the enzyme activity was investigated by adding $\mathrm{K}^{+}, \mathrm{Na}^{+}, \mathrm{Hg}^{2+}, \mathrm{Pb}^{2+}, \mathrm{Cu}^{2+}, \mathrm{Cd}^{2+}, \mathrm{Zn}^{2+}, \mathrm{Ba}^{2+}, \mathrm{Mg}^{2+}, \mathrm{Ca}^{2+}$ and $\mathrm{Al}^{3+}$ metal ions to the reaction mixture. The final concentration of each metal ion was $1 \mathrm{mM}$. Each ion was incubated for $30 \mathrm{~min}$ at a ratio of 1:1 (enzyme: ion). The activity was calculated as the ratio between the enzyme activity measured at the end and at the beginning of the reaction, expressed as percentage (\%). The enzyme activity assayed in a metal-free control sample was considered as $100 \%$ (PARK et al., 2002). Effect of Inhibitors - The enzyme sensitivity to inhibitors was tested by using: phenylmethylsulfonyl fluoride (PMSF), a serine-protease inhibitor; N-ptosyl-L-lysin chloromethyl ketone (TLCK), a trypsin-specific inhibitor; benzamidine, a trypsin inhibitor; N-tosyl-L-phenylalaninechloromethyl ketone (TPCK), a chymotrypsinspecific inhibitor, all of them diluted in DMSO; ethylenediamine tetra-acetic acid (EDTA), a chelating compound; and $\beta$-mercaptoethanol, a reducing agent, diluted in deionized water. The final concentration of each inhibitor was $8 \mathrm{mM}$. Each ion was incubated for 30 minutes at a ratio of 1:1 (enzyme: inhibitor). The activity was compared to the reaction in absence of the corresponding inhibitor and determined as the percentage of the proteolytic activity in an inhibitor-free control sample (PARK et al., 2002).

\subsection{Statistical analysis}

All values are presented as mean \pm standard deviations. These data were statistically analyzed by ANOVA, followed by a post hoc (Tukey) test, when indicated. Differences between groups were accepted as significant at a confidence level of $95 \%(p<0.05)$.

\subsection{Assay for substrate specificity}

The analysis of the digestion of native collagen from bovine Achilles tendon type I was performed according to the method described by Park et al. (PARK et al., 2002) and Moore and Stein (MOORE and STEIN, 1954) with a slight modification. One unit (U) of enzyme activity was defined as the amount of enzyme required for the hydrolysis of $1 \mathrm{mmol}$ of substrate per hour.

\section{RESULTS AND DISCUSSIONS}

3.1 Effect of independents variables on the partition coefficient of collagenase extraction using ATPS

A new collagenolytic protease isolated from peacock bass $C$. ocellaris was obtained according to the steps mentioned. The independent variables PEG molar mass, phosphate salt concentration and the PEG concentration and PEG molar mass interaction were statistically significant at a confidence level of $95 \%$. In the majority of runs, collagenolytic protease partition occurred preferentially on the top PEG-rich phase. The interaction of $\mathrm{C}_{\mathrm{PEG}}$ and $\mathrm{M}_{\mathrm{PEG}}$ displayed negative effects, indicating that the increase on $\mathrm{C}_{\mathrm{PEG}}$ and a decrease on $\mathrm{M}_{\mathrm{PEG}}$, or the opposite, improve the enzyme partition to top PEG-rich phase. The results of this work indicate that the polymer size not creates a repulsive effect on collagenolytic protease partition, and the interaction of both variables is more significant in the coefficient partition. The lower molecular weight PEGs interact strongly with proteins, whilst higher molecular weight PEGs have the ability to form intramolecular bonds. 
3.2 Protease partition, yield and purification factor

The partition of the collagenolytic protease using PEG/phosphate ATPS showed different yield percentages (from 37 to $169 \%$ ). Yields above and around 100\% are often reported for enzyme extraction by ATPS. The observed results are probably explained by the elimination of inhibitors during the purification process and by the composition of the system, since PEG can modify the structure of the enzyme active site and favor the enzymatic activity (MAYERHOFF et al., 2004).

The main variables that influenced the yield response were PEG molar mass and phosphate salts concentration (Figure 1). The effects of the $\mathrm{C}_{\mathrm{PHO}}$ and $\mathrm{M}_{\mathrm{PEG}}$ interaction were negative, what means that high phosphate concentration partition the collagenolytic protease in to the PEG-rich phase. That partition would be justified by a salting out effect, where the biomolecule moves to the other phase because of the great amount of salt in the bottom phase (YANG et al., 2008).

Figure 1. Pareto chart of standardized effects of the factors. (1) PEG MM: polyethylene glycol molar mass; (2) $\mathrm{C}_{\mathrm{PEG}} \%$ : polyethylene glycol concentration; (3) $\mathrm{pH}$ : $\mathrm{pH}$ factor; (4) Cfos\%: phosphate concentration on the variable Kin $2^{4}$-full factorial design1 by $2,3,4 ; 3$ by $4 ; 2$ by 3,4 are the interaction effects between the factors.

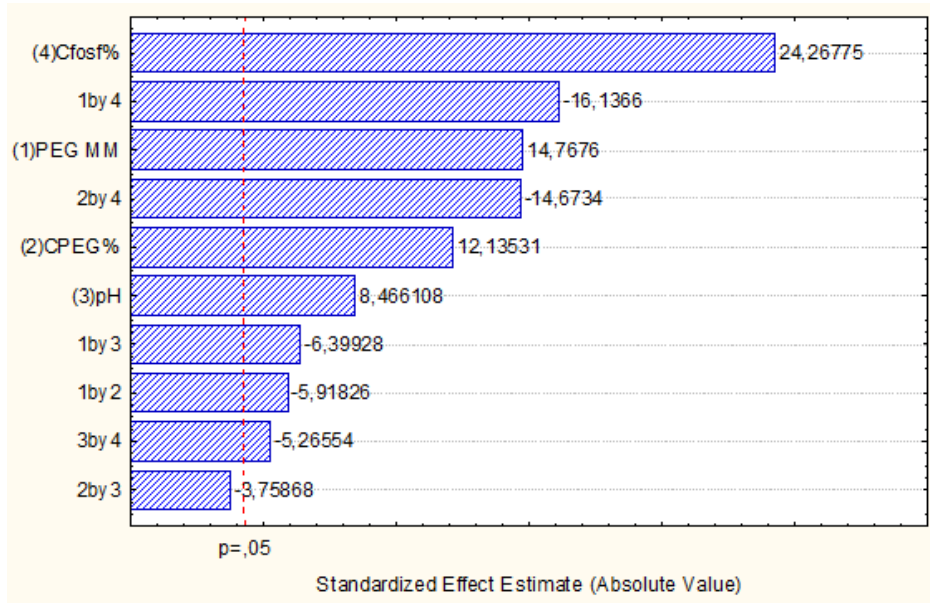

The statistical analysis of the purification factor $(P F)$ was also in agreement with the yield response, i.e. the negative effect of the $\mathrm{C}_{\mathrm{PHO}}$ and $\mathrm{M}_{\mathrm{PEG}}$ interaction influenced negatively the $P F$. According to the statistical analysis, $\mathrm{pH}$ increase has a positive effect in the yield and volumetric protease activity, i.e. at alkaline $\mathrm{pH}$, protein partition has preference for the top PEG-rich phase. The $\mathrm{pH}$ of the system influences the ionizable groups of a protein and alters its surface charges. At high $\mathrm{pH}$ values, the protein is more negatively charged than at low $\mathrm{pH}$, and therefore, the partition coefficient of the protein increases with increasing the $\mathrm{pH}$ (SARAVANAN et al., 2008), which may be due to the electrostatic interactions between the protein and the PEG units.

The best results from the statistical analysis of the three variables responses $(K, Y$ and $P F)$, were obtained in the run $6\left(\mathrm{pH} 8.0\right.$, MPEG $8000 \mathrm{~g} / \mathrm{mol}, \mathrm{C}_{\mathrm{PEG}} 12.5 \% \mathrm{w} / \mathrm{w}$ and $\mathrm{C}_{\mathrm{PHO}} 10 \%$ $\mathrm{w} / \mathrm{w})$. These results are in agreement with the theory that hydrogen ion forces favor the partition into the top phase, where a major purification occurred due an alkaline $\mathrm{pH}$. The validity of the model was verified by analysis of variance and all determination coefficient$\mathrm{R}^{2}$ were around 0.80 , where a value close to 1 indicates agreement between the experimental data and the model predicted. The estimated effects and the corresponding $p$-values indicate that the independent variables had a significant effect on the response studied $(p<0.05)$. When compared to other purification techniques used to isolate collagenolytic proteases of fish, the 
ATPS system showed a PF close to that extracted by DEAE Sephadex A-50, highlighting the advantages of using ATPS for collagenase extraction, as mentioned by Rosso et al (2012), which obtained an efficient method for collagenase recovery $\left(\mathrm{M}_{\mathrm{PEG}} 550 \mathrm{~g} / \mathrm{mol}, \mathrm{PF}: 23.5, \mathrm{pH}\right.$ $6.0, \mathrm{~K}: 1.01, \mathrm{y}: 242 \%)$.

\subsection{Effect of temperature and $\mathrm{pH}$ on PEG-collagenolytic activity}

The effects of the temperature and $\mathrm{pH}$ on the PEG-collagenolytic protease activity were investigated and the maximum activity was observed at $55^{\circ} \mathrm{C}$, corroborating reports of collagenolytic enzymes purified from other fish species, such as filefish species Novoden modestrus (KIM et al., 2002), tuna Thunnus thymus (BYUN et al., 2002) and mackerel species Scomber japonicus (PARK et al., 2002). The enzyme was inhibited more than $50 \%$ after to be exposed to a temperature of $65^{\circ} \mathrm{C}$, temperature in which the molecular kinetic energy becomes large enough to start the denaturation of the enzyme molecule itself leading to a consequent sharp decrease in the enzyme activity.

The effect of $\mathrm{pH}$ was investigated at $\mathrm{pH}$ values ranging from 4 to 12 . The optimal activity was observed at $\mathrm{pH} 7.5$, with a residual activity of $60 \%$ at $\mathrm{pH}$ values in the range of 6.5 to 9.5 . The optimum $\mathrm{pH}$ found in this work is similar to the ones reported for mackerel species S. japonicus (PARK et al., 2002). Parameters such as temperature and $\mathrm{pH}$ are limiting factors for a good performance of collagenolytic enzymes during the production of peptides.

\subsection{Metal ions and inhibitors effect on PEG-collagenolytic activity}

Only $\mathrm{Ca}^{2+}$ and $\mathrm{Mg}^{2+}$ did not affect the enzyme activity significantly $(\mathrm{p}<0.05)$ when compared to the control group. The enzyme was inhibited by the following metal ions, in descending order: $\mathrm{Al}^{3+}, \mathrm{Cu}^{2+}, \mathrm{Hg}^{2+}, \mathrm{Cd}^{2+}, \mathrm{Pb}^{2+}, \mathrm{Zn}^{2+}$ and $\mathrm{Mg}^{2+}$. These results are in agreement with those described for purified collagenolytic enzymes from filefish $N$. modestrus (KIM et

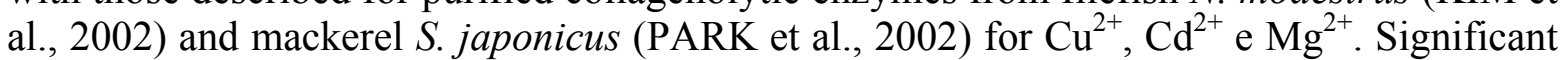
differences between all the treatments compared to the control group were found for the assays in the presence of inhibitors. The highest degree of inhibition was obtained by using trypsin inhibitors (Benzamidine and TLCK), although it was also detected high degree of inhibition $(67.03 \%)$ by the serine protease inhibitor (PMSF). In the presence of the metalloprotease inhibitor (EDTA) the activity was only partially inhibited, when compared to the other inhibitors studied.

Enzymes belonging to the class of metalloproteases generally require $\mathrm{Zn}^{2+}$ to maintain their optimum activity and stability, at the same time that their activities are significantly reduced after exposure to EDTA, a chelating agent for the $\mathrm{Ca}^{2+}$ ion. Thus, the increase in activity induced by $\mathrm{Ca}+$ and the inhibition brought about by classical inhibitors of serine proteases, besides the capacity to cleave collagen type I, suggest that the enzyme in question belongs to the group of serine collagenolytic proteases, such as those described for the species of tuna fish filefish N. modestrus (KIM et al., 2002), Mackerel S. japonicus (PARK et al., 2002) and for smooth weakfish Cynoscion leiarchus (OLIVEIRA et al., 2017).

\subsection{Hydrolysis of collagen by PEG-collagenolytic protease}

The enzyme showed specificity for the type I collagen and was able to cleave collagen after 24 hours of incubation, reaching maximum activity at 48 hours. The results are similar to those reported for collagenases from fish waste processing, such as described for Mackerel S. japonicus (PARK et al., 2002) and smooth weakfish C. leiarchus (OLIVEIRA et al., 2017).

\section{CONCLUSIONS}

A protease with collagenolytic properties was successfully recovered from peacock bass 
C. ocellaris, by PEG/phosphate aqueous two phase system, and biochemically characterized for industrial purposes. The highest value of $P F(8.24)$, obtained using $20.0 \%(\mathrm{w} / \mathrm{w})$ PEG 8000 and $12.5 \%(\mathrm{w} / \mathrm{w})$ phosphate at $\mathrm{pH} 8.0$, was better than those reported in the literature for similar processes. The method here described is suggested to be used in the initial stages of a purification process allowing the removal of contaminants by a fast, simple and economical process, or even as a primary purification step, meeting the need for isolation and production of collagen peptides. ATPS was proved to be a promising method to recover collagenolytic proteases from fish processing waste on an industrial scale, regarding the food, pharmaceutical and cosmetics sectors.

\section{REFERENCES}

BYUN, H.G.; PARK, P.J.; SUNG, N.J.; KIM, S.K. Purification and characterization of a serine proteinase from the tuna pyloric caeca. J. Food Biochem., 26, 479-494, 2002.

ERDMANN, K.; CHEUNG, B.W.Y.; SCHRÖDER, H. The possible roles of food-derived bioactive peptides in reducing the risk of cardiovascular disease. J. Nutr. Biochem. 19(10), 643-654, 2008.

HARTMANN, R.; MEISEL, H. Food-derived peptides with biological activity: from research to food applications. Curr. Opin. Biotechnol., 18(2), 163-169, 2007.

HATTI-KAUL, R. Aqueous Two-Phase Systems. Mol. Biotechnol., 19, 269-277, 2001.

KIM, S.K.; PARK, P.J.; KIM, J.B.; SHAHIDI, F. Purification and characterization of a collagenolytic protease from the filefish, Novoden modestrus. J. Biochem. Mol. Biol. 35(2), 165-171, 2002.

MAYERHOFF, Z.D.V.L.; ROBERTO, I.C.; FRANCO, T.T. Purification of xylose reductase from Candida mogii in aqueous two-phase systems. Biochem. Eng. J. 18(3), 217-223, 2004.

MOORE, S.; STEIN, W. A modified ninhydrin reagent for the photometric determination of amino acids and related compounds. J. Biol. Chem. 211, 907-913, 1954.

OLIVEIRA, V.M.; ASSIS, C.R.D.; HERCULANO, P.N.; CAVALCANTI, M.T.H.; BEZERRA, R.S.; PORTO, A.L.F. Collagenase from smooth weakfish: extraction, partial purification, characterization and collagen specificity test for industrial application. B. Inst. Pesca. 43(1), 52-64, 2017.

PARK, J.P.; LEE, S.H.; BYUN, H.G.; KIM, S.H.; KIM, S.K. Purification and Characterization of a Collagenase from the Mackerel, Scomber japonicas. J. Biochem. Mol. Biol. 35(6), 576-582, 2002.

RAJA, S.; MURTY, V.R.; THIVAHARAN, V.; RAJASEKAR, V.; RAMESH, V. Aqueous Two Phase Systems for the Recovery of Biomolecules - A Review. Sci. Technol., 1(1), 7-16, 2011.

ROSSO, B.U.; LIMA, C.A.; PORTO, T.S.; NASCIMENTO, C.O.; PESSOA JUNIOR, A.; CONVERTI, A.; MARQUES, D.A.V.; CARNEIRO-DA-CUNHA, M.G.; PORTO, A.L.F. Partitioning and extraction of collagenase from Penicillium aurantiogriseumin poly(ethylene 
glycol)/phosphate aqueous two-phase system. Fluid Phase Equilib. 335, 20-25, 2012.

SARAVANAN, S.; RAO, J.R.; NAIR, B.U.; RAMASAMI, T. Aqueous two-phase poly(ethylene glycol)-poly(acrylic acid) system for protein partitioning: Influence of olecular weight, pH and temperature. Process Biochem. 43(9), 905-911, 2008.

SMITH, P.K.; KROHN, R.I.; HERMANSON, G.T.; MALLIA, A.K.; GARTNER, F.H.; PROVENZANO, M.D.; FUJIMOTO, E.K.; GOEKE, N.M.; OLSON, B.J.; KLENK, D.C. Measurement of protein using bicinchoninic acid. Anal. Biochem., 150, 76-85, 1985.

STATSOFT INC., STATISTICA (Data Analysis Software Systems) Version 8.0, 2008.

YANG, S.; HUANG, Z.; JIANG, Z.; LI, L.; YANG, S.; HUANG, Z.; JIANG, Z.; LI, L. Partition and Purification of a Thermostable xylanase produced by Paecilomyces thermophila in Solid-state Fermentation Using Aqueous Two-phase Systems. Process Biochem. 43(1), 56-61, 2008.

\section{ACKNOWLEDGEMENTS}

This work was supported by the National Council of Technological and Scientific Development (CNPq) (Grant number: 141465/2011-5; 306563/2011-8) and Foundation for Science and Technology of the State of Pernambuco (FACEPE) (Grant number: BFP-0115$5.05 / 14)$. 